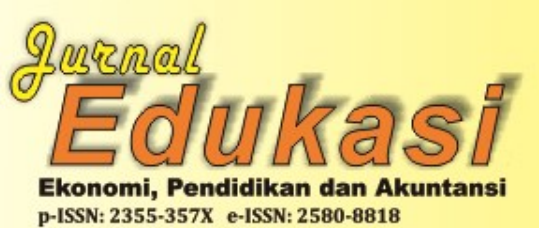

Program Studi Pendidikan Akuntansi

Fakultas Keguruan Dan Ilmu Pendidikan UNIVERSITAS GALUH CIAMIS Jl. R. E. Martadinata No. 150 Ciamis, 46274 Jawa Barat $+62265-776787$

https://jurnal.unigal.ac.id/index.php/edukasi/article/view/4030

\title{
PENGARUH KEPEMILIKAN INSTITUSIONAL, UKURAN DEWAN KOMISARIS, UKURAN PERUSAHAAN, DAN UKURAN KOMITE AUDIT TERHADAP PENGUNGKAPAN CSR
}

\author{
Oleh: \\ Tio Sandi Boy Sihombing ${ }^{1}$, Herlina Banjarnahor ${ }^{2}$, Winda Alfionita ${ }^{3}$, Deasy Arisandy Aruan ${ }^{4}$ \\ Fakultas Ekonomi Universitas Prima Indonesia \\ Jl. Belanga No.1, Sei Putih Tengah, Kec. Medan Petisah, Kota Medan, Sumatera Utara \\ Sandisihombing1998@gmail.com \\ Sejarah Artikel: Diterima September 2020, Disetujui Oktober 2020, Dipublikasikan November 2020
}

\begin{abstract}
ABSTRAK
Tujuan penelitian ini untuk mengetahui faktor-faktor yang mempengaruhi CSR pada perusahaan Industri Dasar dan Kimia. Sampel diambil dengan menggunakan metode purposive sampling. Sampel merupakan laporan tahunan perusahaan Industri Dasar dan Kimia tahun 2014-2017. Metode analisis yang digunakan adalah analisis regresi linier berganda dengan bantuan program SPSS. Hasil penelitian ini menunjukkan bahwa uji anova atau $\mathrm{F}$ test, menunjukkan Kepemilikan Institusional, Ukuran Dewan Komisaris, Ukuran Perusahaan, Komite Audit. Berpengaruh Signifikan dan Simultan terhadap CSR Pada perusahaan Industri Dasar dan Kimia. Kemudia dari hasil uji secara parsial dengan mengunakan uji t diketahui variabel independen kepemilikan institusioanl tidak berpengaruh signifikan dan negatif terhadap pengungkapan CSR, variabel independen ukuran dewan komisaris berpengaruh signifikan dan positif terhadap CSR, variabel independen ukuran dewan komisaris tidak berpengaruh signifikan dan negatif terhadap CSR, variabel independen ukuran perusahaan tidak berpengaruh signifikan dan negatif terhadap CSR, dan variabel independen ukuran komite audit berpengaruh signifikan dan positif terhadap CSR.
\end{abstract}

Kata Kunci: Kepemilikan Institusional, Komisaris, Ukuran Perusahaan.

\section{ABSTRACT}

This study aimed to determine the factors that influence CSR in basic industrial companies and chemicals. Samples were taken using a purposive sampling method. The sample is an annual report of the Basic Industry and Chemical companies for the years 2014-2017. The analytical method used is multiple linear regression analysis with the help of the SPSS program. This study indicates that the ANOVA test or the F test shows Institutional Ownership, Board of Commissioners Size, Company Size, Audit Committee. It was a significant and simultaneous effect on CSR in basic industry and chemical companies. Then from the partial test results using the test, it is known that the independent variable of institutional ownership does not have a significant and negative effect on CSR disclosure, the independent variable board size has a significant and positive effect on CSR, the independent variable board size has no significant and negative effect on CSR, the variable, independent firm size has no significant and negative effect on CSR, and the independent variable audit committee size has a significant and positive effect on CSR

Keywords: Institutional Ownership, Commissioners, Company Size.

\section{PENDAHULUAN}

Kemajuan sektor bisnis menjadikan ketatnya persaingan para pemilik usaha. Perkembangan aktivitas bisnis turut memberi pengaruh pada lingkungan, khusunya dalam sektor yang memanfaatkan sumber daya alam. Contoh dampak tersebut yakni misalnya, permasalahan terkait tenaga kerja, keamanan produk, limbah, serta polusi. Lingkungan rusak serta tingginya kesenjangan sosial karena 
kegiatan operasional perusahan guna mendapat laba. Fenomena ini menjadikan perspektif masyarakat terkait peranannya dalam bertanggung jawab pada lingkungan, cara pandang ini disebut CSR. Secara umum sektor bisnis berfokus pada untung yang tinggi tanpa memperhatikan akibat dari bisnisnya. Pengusaha dituntut guna bisa memperhatikan lingkungan sosial di sekitarnya. Sehingga muncullah Undang-Undang Nomor 40 tahun 2007 tentang Perseroan Terbatas dimana ayatnya menuntut seluruh perusahaan di sektor sumber daya alam guna menjalankan tanggung jawab lingkungan serta sosialnya.

Komitmen perusahaan supaya turut serta membangun bangsa melalui pemerhatian pada aspek perekonomian, lingkungan serta sosial. Suatu komponen industri yang sedang memiliki perkembangan bagus di Indonesia yakni Industri dasar dan Kimia. (dalam https://investasi.kontan.co.id/news/naiktertinggi-saham-sektor-industri-dasar-dankimia-terimbas-sentimen-positif) BEI atau Bursa Efek Indonesia memaparkan jika satu bidang industri yang memiliki perkembangan paling baik selama 2018 yakni industri dasar dan kimia, dengan peningkatan mencapai $21,17 \%$, IHSG atau indeks harga saham gabungan turun 3,02\% ytd menuju level 6.163 dalam penutupan perdagangan. Sehingga laju tumbuh industri dasar dan kimia cenderung bertambah signifikan.

Perusahaan cenderung mengeluarkan biaya guna melangsungkan tanggung jawab sosial yang dimiliki, kondisi ini memberi pengaruh pada turunnya pendapatan perusahaan. Namun perusahaan yang melakukan tanggung jawab sosal cenderung memperoleh besarnya loyalitas konsumen, khususnya terkait berbagai produk ramah lingkungan. Perusahaan besar yang memiliki tingginya profitabilitas cenderung memaparkan informasi sosial yang juga besar. Kondisi ini timbul dikarenakan sorotan masyarakat yang besar terkait perusahaan yang dimaksud.

Kepemilikan institusional penting dalam memonitoring kinerja suatu perusahaan. Kepemilikan institusional sama dengan halnya dengan kepemilikan suatu perusahaan. Bertambah banyak saham yang ada dalam perusahaan tersebut, menjadikan bertambah tinggi pula pengaruh kepemilikan institusional dalam pengembangan perusahaan termasuk CSR. Tinggi nya kepemilikan oleh institusi akan menaikkan pengawasan kinerja perusahaan.

Suatu perusahaan pada dasarnya memiliki susunan organisasi dewan komisaris. Fungsi dewan komisaris tentunya harus sejalan dengan kegiatan usahanya yaitu dengan mengendalikan proses kinerja perusahaan sehingga menghasilkan citra perusahaan dihadapan masyarakat.

Ukuran perusahaan memeriksa taraf suatu perusahaan. Umumnya perusahaan besar mempunyai kegiatan yang cenderung berbelit serta banyak, memperoleh perhatian lebih dari khalayak umum, mempunyai shareholder yang banyak, serta memiliki risiko cenderung besar. Kondisi tersebut menjadikan perusahaan besar memiliki tuntuan berlebih terkait pengungkapan tanggung jawaban sosial yang dimilikinya, oleh karenanya perusahaan dengan ukuran besar cenderung sangat banyak menunjukkan informasi terkait kegiatannya.

Komite audit terdiri dari beberapa auditor yang memiliki tugas dalam mengaudit suatu laporan keuangan perusahaan, yang mana secara tidak langsung bertanggung jawab terhadap dewan komisaris. Tidak terlepas juga bahwa hasil audit yang baik tersebut akan meningkatkan kepercayaan masyarakat dan akan membawa manajemen tersebut untuk mempertanggung jawab kan CSR yang ada.

Semakin bagus kinerja perusahaan yang dipaparkan pada laporan keuangan, menjadikan bertambah bagus citra perusahaan oleh karenanya bertambah juga investor yang hendak menanam modal. Untuk itu terkait paparan di atas, menjadikan peneliti ingin menguji kembali, pengaruh ukuran komite audit, ukuran perusahaan, ukuran dewan komisaris, serta kepemilikan institusional terhadap pengungkapan csr pada perusahaan penelitian. 


\section{Kerangka Konseptual}

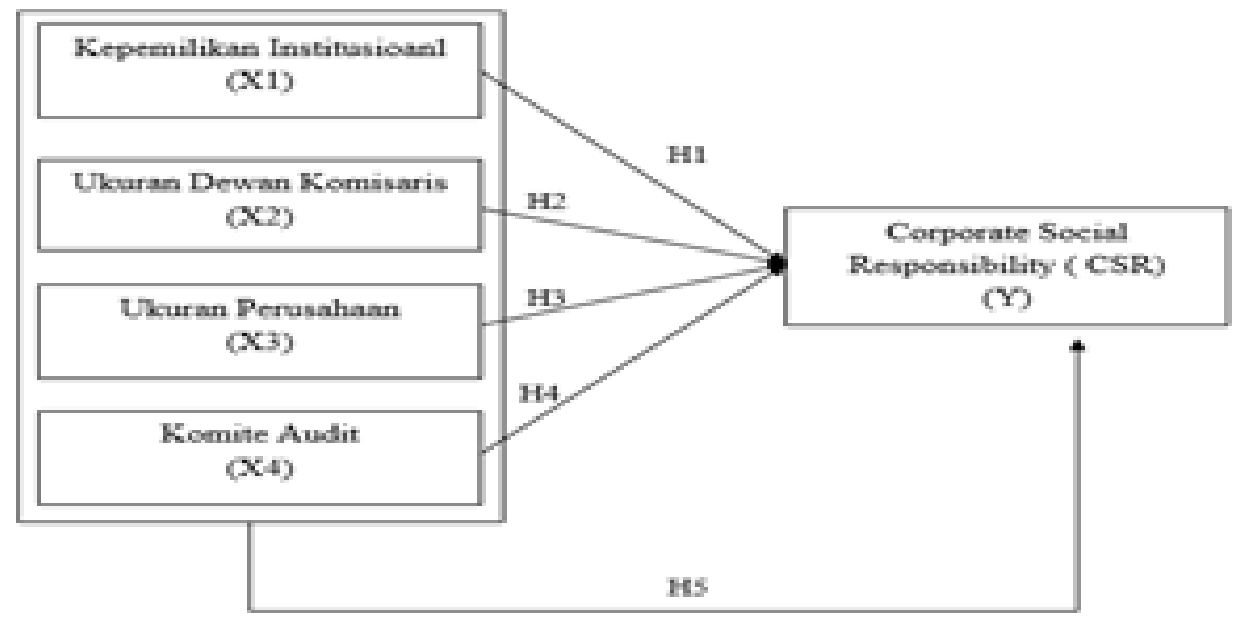

Gambar 1:

Kerangka Komseptual

$\mathrm{H}_{1}=$ Kepemilikan Institusioal berpengaruh terhadap CSR

$\mathrm{H}_{2}=$ Ukuran dewan komisaris berpengaruh terhadap CSR

$\mathrm{H}_{3}=$ Ukuran perusahaan berpengaruh terhadap CSR

$\mathrm{H}_{4}=$ Komite audit berpegaruh terhadap CSR

$\mathrm{H}_{5}=$ Kepemeikian Institusional, Ukuran Dewan Komisaris, Ukuran Perusahaan, Ukuran Komite Audit berpengarus Signifikan terhadap pengungkapan CSR

\section{METODE PENELITIAN}

\section{Jenis Penelitian}

Penelitian ini menggunakan pendekatan kuantitatif dengan melakukan pengujian hipotesis. Penelitian ini mengenai Pengaruh Kepemilikan Institusional, Ukuran Dewan Komisaris, Ukuran Perusahaan, Dan Ukuran Komite Audit Terhadap Pengungkapan CSR pada perusahaan Industri Dasar dan Kimia yang terdaftar di Bursa Efek Indonesia.

\section{Teknik Pengambilan Sampel}

Populasi yang digunakan dalam penelitian ini adalah seluruh laporan keuangan perusahaan Industri dasar dan kimia yang terdaftar di BEI pada periode 2014-2017. Teknik pengambilan sampel yang di pakai dalam penelitian ini adalah purposive sammpling. Adapun kriteria pengambilan sampel sebagai berikut:

Tabel 1:

Kriteria Pengambilan Sampel

\begin{tabular}{clc}
\hline No & \multicolumn{1}{c}{ Krite } & $\begin{array}{c}\text { Jumlah } \\
\text { Sampel }\end{array}$ \\
\hline \multirow{2}{*}{1} & $\begin{array}{l}\text { Perusahaan Dasar dan Kimia yang } \\
\text { Terdaftar Di BEI }\end{array}$ & 64 \\
2 & Perusahaan Yang Tidak & $(24)$ \\
3 & Mempublikasihkan Laporan & $(13)$ \\
Data Sampel Tidak Mengunakan Rupiah & Jumlah Sampel Peneliti & 32 \\
& Jumlah Observasi Penelitian (32 X 4 & 128 \\
\hline
\end{tabular}




\section{Teknik Pengumpulan Data}

Teknik pengumpulan data yang digunakan dalam penelitian ini adalah studi dokumentasi yang dilakukan melalui pengumpulan data dari jurnal,buku dan media perantara internet melalui situs www.idx.co.id.

\section{HASIL PENELITIAN DAN PEMBAHASAN Statistik Deskriptif}

Data statistik deskriptif diperoleh sebanyak 128 data observasi yang berasal dari perkalian antara periode penelitian (4 tahun yaitu dari tahun 2014 sampai 2017) dengan jumlah perusahaan sampel berjumlah 32 perusahaan.

\section{Statistik Deskriptif Variabel Penelitian}

Tabel 2:

Descriptive Statistics

\begin{tabular}{lrrrrr}
\hline & \multicolumn{1}{c}{ N } & Minimum & Maximum & \multicolumn{1}{c}{ Mean } & \multicolumn{1}{c}{ Std. Deviation } \\
SQRT_KEPEMILIKANINSTITUSIONAL & 128 &, 43 & 2,85 & 1,0061 &, 21336 \\
SQRT_UKURANDEWANKOMISARIS & 128 & 1,41 & 2,65 & 1,9578 &, 33632 \\
SQRT_UKURANPERUSAHAAN & 128 & 4,33 & 5,57 & 5,1744 &, 27878 \\
SQRT_UKURANKOMITEAUDIT & 128 & 1,41 & 2,24 & 1,7700 &, 12444 \\
SQRT_CSR & 128 &, 23 &, 59 &, 4519 &, 09523 \\
Valid N (listwise) & 128 & & & & \\
\hline
\end{tabular}

Berdasarkan tabel 2 dapat dilihat bahwa :

1. Dari hasil pengujian variabel kepemilikan institusional $\left(\mathrm{X}_{1}\right)$, yaitu 0,43 dan maximum 2,85 dengan kata lain interval berkisaran 0,43 samapi 2,85 dengan rata-rata 1,00 lebih tinggi dibandingkan standar deviasi nya 0,21 yang menunjukkan data variabel kepemilikan institusioanl $\left(\mathrm{X}_{1}\right)$ bervariasi.

2. Dari hasil pengujian variabel ukuran dewan komisaris $\left(\mathrm{X}_{2}\right)$, memiliki nilai minimum 1,41 dan maximum 2,65. Dengan kata lain interval berkisar 1,41 sampai 2,65 dengan rata-rata 1,95 lebih tinggi dibandingkan standar deviasi nya 0,33 yang menunjukkan data variabel ukuran dewan komisaris $\left(\mathrm{X}_{2}\right)$ bervariasi.

3. Dengan hasil pengujian variabel ukuran perusahaan $\left(\mathrm{X}_{3}\right)$, memiliki nilai minimum 4,33 dan maximum 5,57. Dengan kata lain interval berkisar 4,33 sampai 5,57 dengan rata-rata 5,17 lebih tinggi dibanding standar deviasi nya 0,27 yang menunjukkan data variabel ukuran perusahaan $\left(\mathrm{X}_{3}\right)$ bervariasi.

4. Dengan hasl pengujian variabel ukuran komite audit $\left(\mathrm{X}_{4}\right)$, memiliki nilai minimum 1,41 dan maximum 2,24. Dengan kata lain interval berkisar 1,41 sampai 2,24 dengan rata-rata 1,77 lebih tinggi dibandingkan deviasi nya 0,12 yang menunjukkan data variabel ukuran komite audit $\left(\mathrm{X}_{4}\right)$ bervariasi.

\section{UJI ASUMSI KLASIK Uji Normalitas}

Tabel 3:

\begin{tabular}{ll}
\multicolumn{2}{c}{ One-Sample Kolmogorov-Smirnov Test } \\
\hline $\mathrm{N}$ & Unstandardized Residual \\
Kolmogorov-Smirnov Z & 128 \\
Asymp. Sig. (2-tailed) &, 929 \\
\hline
\end{tabular}

Berdasarkan tabel 3 besarnya nilai Kolmogorov-Smirnov adalah 0,929 dan nilai signifikansi dari unstandardized residual sebesar 0,354. nilai signifikansi tersebut lebih besar dari 0,05 oleh karena itu, dapat dikatakan bahwa hasil uji normalitas dengan Kolmogorov-Smirnov data secara umum terdistribusi normal. Hasil ini diperkuat dengan hasil P-Plot pada gambar 1 di bawah ini: 


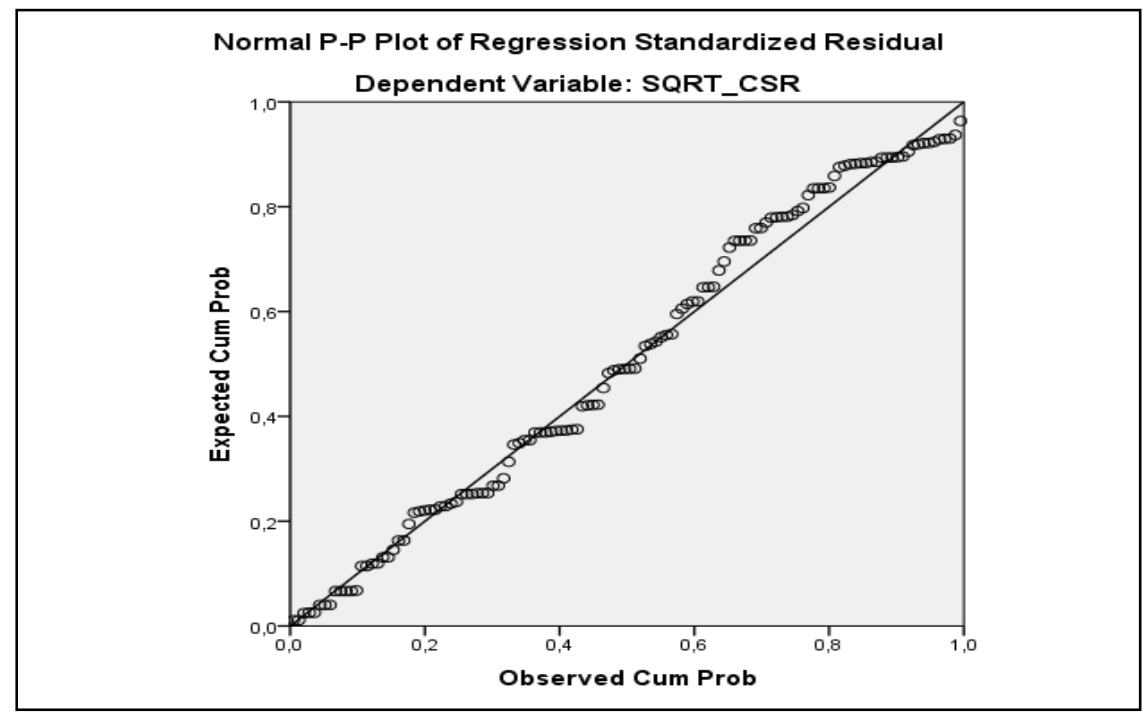

Gambar 2:

hasil Uji Normalitas

Berdasarkan tampilan gambar 2 dapat dilihat bahwa data menyebar disekitar garis diagonal dan mengikuti arah.

\section{Uji Multikolinieritas}

Tabel 4:

Coefficients $^{\mathrm{a}}$

\begin{tabular}{lcc}
\multicolumn{1}{c}{ Model } & \multicolumn{2}{c}{ Collinearity Statistics } \\
\hline & Tolerance & VIF \\
(Constant) & & \\
SQRT_KEPEMILIKANINSTITUSIONAL &, 982 & 1,018 \\
1SQRT_UKURANDEWANKOMISARIS &, 830 & 1,205 \\
SQRT_UKURANPERUSAHAAN &, 933 & 1,071 \\
SQRT_UKURANKOMITEAUDIT &, 815 & 1,227 \\
\hline
\end{tabular}

a. Dependent Variable: SQRT_CSR

Uji multikolonieritas dilaksanakan dengan melihat nilai tolerance dan Variance Inflation Factor (VIF). Nilai cutt off yang umum dipakai untuk memperlihatkan adanya multikolonieritas adalah nilai tolerance $=\leq 0,10$ dan nilai VIF $=\geq 10$. Hasil uji multikolonieritas terdapat pada tabel 4 menunjukkan bahwa tidak terjadi multikolineartitas diantara variabel-variabel independen yang diteliti.

\section{Uji Autokorelasi}

Dasar pengambilan keputusan ada tidaknya autokorelasi dengan menggunakan Durbin Watson

Tabel 5:

Model Summary ${ }^{\mathrm{b}}$

\begin{tabular}{l} 
Model Durbin-Watson \\
\hline$\frac{1.825}{1}$ \\
a. Dependent Variable: SQRT_CSR \\
b. Predictors: (Constant), SQRT_UKURANKOMITEAUDIT, \\
SQRT_KEPEMILIKANINSTITUSIONAL, \\
SQRT_UKURANPERUSAHAAN, SQRT_UKURANDEWANKOMISARIS
\end{tabular}

Hasil yang ditunjukkan pada tabel 5, Durbin Watson dalam penelitian ini adalah $\mathrm{du}<\mathrm{dw}<4$-du $(1,7763<1,825<2,2237)$ maka dapat disimpulkan bahwa tidak terjadi autokerelasi model regresi yang terbentuk. 


\section{Uji Heterokedastisitas}

Hasil pengujian heterokedastisitas dapat dilihat pada grafik scatterplot dibawah ini:

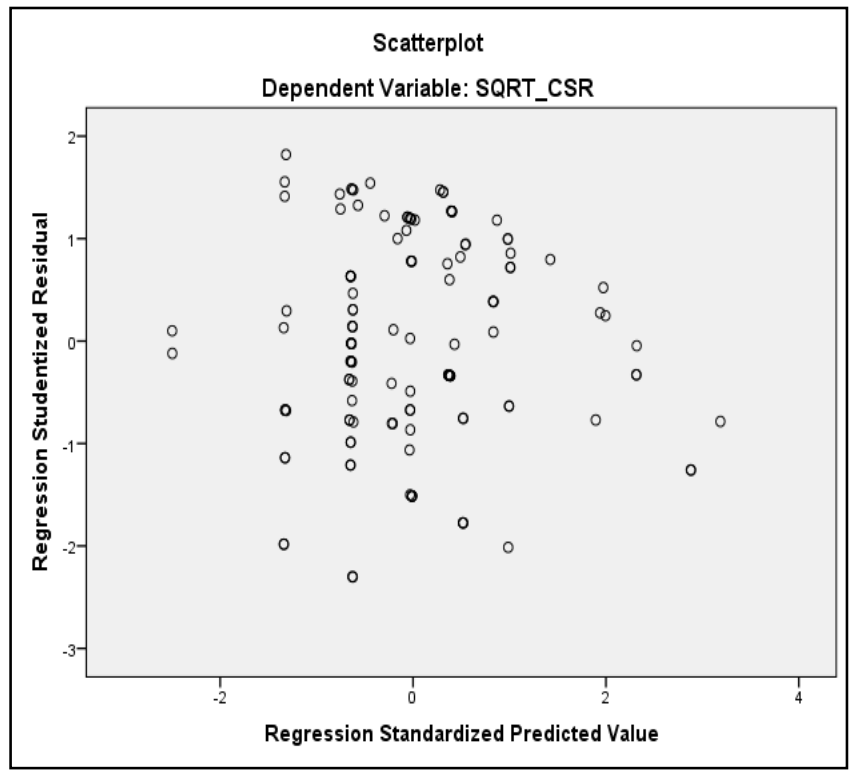

Gambar 3:

Hasil Uji Heterokedastisitas

Grafik Scatterplot

Dari grafik scatterplot pada gambar 3 terlihat titik-titik menyebar secara acak, serta tersebar di atas maupun di bahwa angka 0 (nol) pada sumbu Y. Dengan demikian dapat disimpulkan bahwa model regresi dalam penelitian ini bebas dari heterokedastisitas.

\section{Hasil Analisis Regresi Linear Berganda}

Tabel 6:

Regresi Linear Berganda

Coefficients $^{\mathrm{a}}$

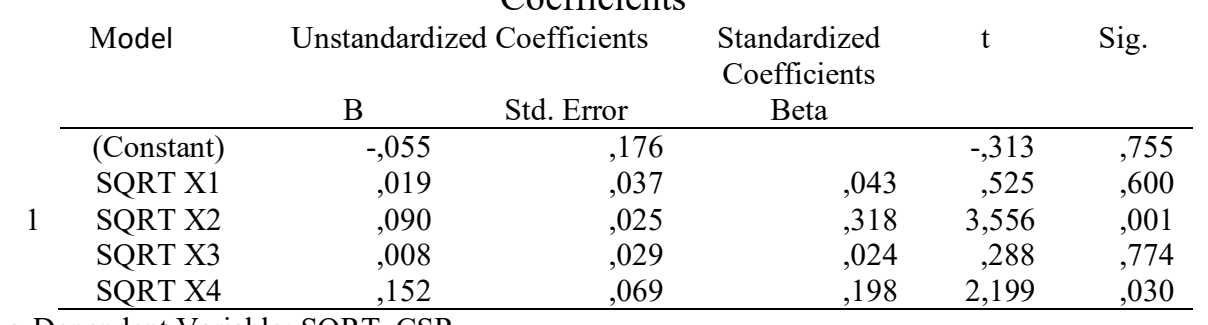

a.Dependent Variable: SQRT_CSR

Berdasarkan tabel 6 dapat diperoleh model penelitian dengan menggunkan transformasi SQRT sebagai berikut :

$$
\mathrm{CSR}=-0,055+0,019 \mathrm{KI}+0,090 \mathrm{UDK}+0,008 \mathrm{UP}+0,152 \mathrm{UKA}
$$

1. Jika variabel kepemilikan institusional, ukuran dewan komisaris, ukuran perusahaan, dan ukuran komite audit bernilai konstan maka nilai CSR menurun senilai -0,055

2. Jika kepemilikan instituional meningkat sebesar satu satuan maka nilai CSR mingkat senilai 0,019

3. Jika ukuran dewan komisaris mingkat satu satuan maka nilai CSR mingkat senilai 0,090

4. Jika ukuran perusahaan meingkat satu satuan maka nilai CSR meningkat senilai 0,008

5. Jika ukuran komite audit meningkat satu satuan maka nilai CSR meningkat senilai 0.152 


\section{Pengujian Hipotesis Koefisien Determinasi $\left(\mathbf{R}^{2}\right)$}

Tabel 7:

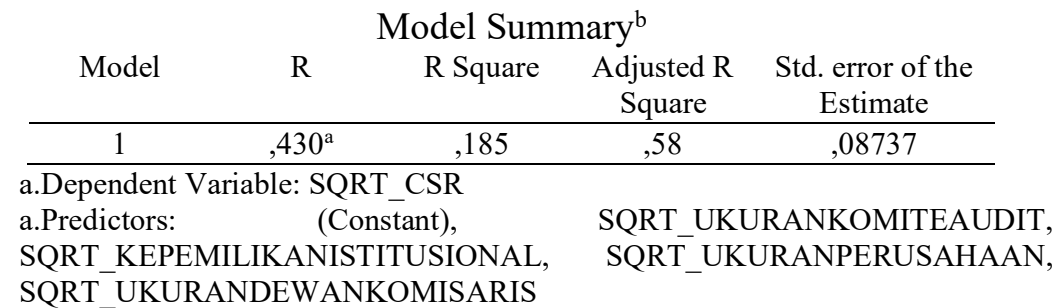

Dari tabel 7 diperoleh Adjusted $R_{\text {Square }}\left(\mathrm{R}^{2}\right)$ sebersar 0,158 dengan demikian variabel (Kepemilikan Institusional, Ukuran dewan komisaris, ukuran Perusahaan, dan Komite audit) dapat menjelaskan variabel pengungkapan CSR sebesar 15,8\% Sedangkan sisanya 84,2\% dipengaruhi oleh variabel-variabel lain yang tidak dimasukkan ke dalam penelitian ini. Seperti leverage,

\section{Uji Simultan (Uji F)}

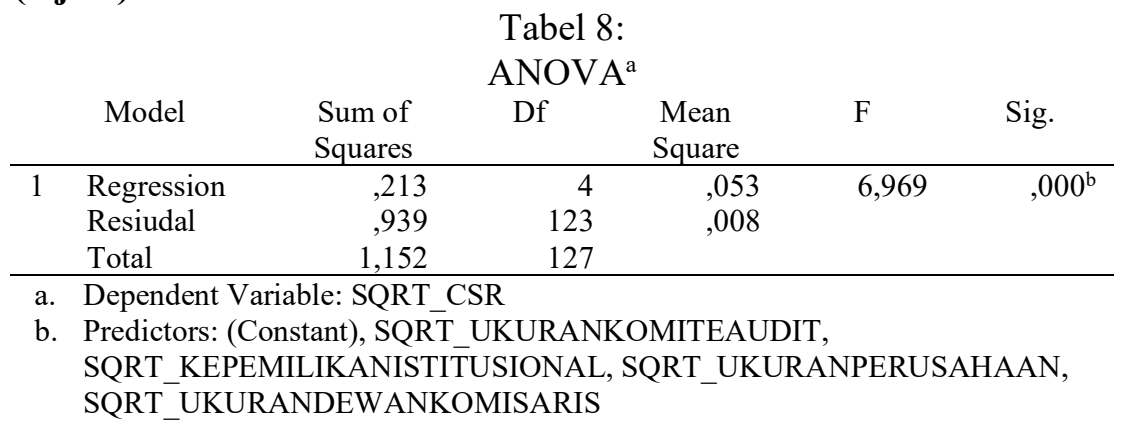

Berdasarkan Tabel 8 diketahui nilai signifikasi untuk pengaruh Kepemilikan Institusional, Ukuran Dewan Komisaris, Ukuran Perusahaan, Komite Audit. Secara simultan Terhadap CSR, adalah Sebesar $0,000<0,05$ dan nilai $F_{\text {hitung }} 6,969>F_{\text {tabel }} 2,44$ sehingga dapat disimpulkan bahwa Kepemilikan Institusional, Ukuran Dewan Komisaris, Ukuran Perusahaan, Komite Audit. Berpengaruh Simultan terhadap CSR.

\section{Hasil Uji Hipotesis t}

Tabel 9:

Coefficients $^{\mathrm{a}}$

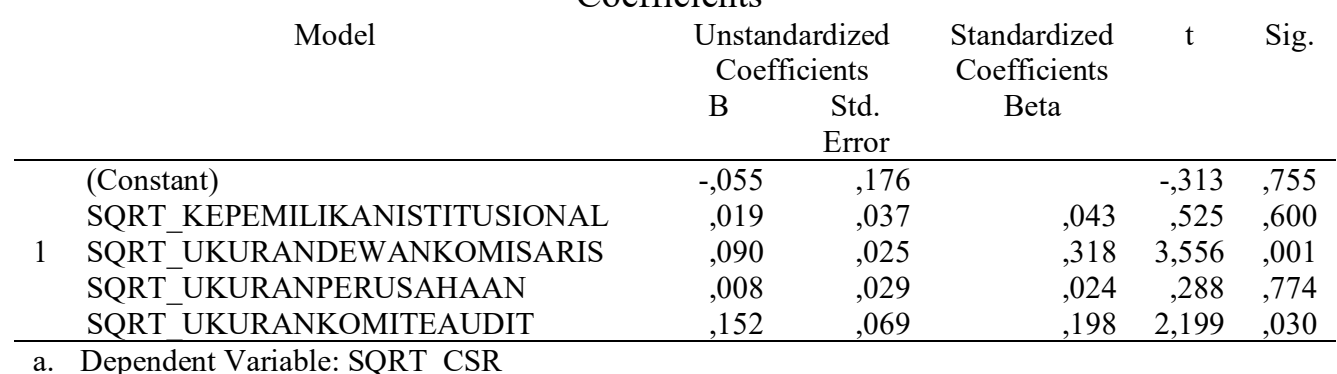

Berdasarkan hasil uji $\mathrm{t}$ yang terdapat pada tabel 9 dapat digambarkan sebagai berikut:

\section{Pengaruh Kepemilikan Institusional $\left(X_{1}\right)$ Terhadap Pengungkapan CSR (Y)}

Dari hasil uji t, diperoleh nilai thitung 0,525 dan. $t_{\text {tabel }}$ sebesar 1,979 dengan nilai signifikasi
0,600. Dimana didapatkan $t_{\text {hitung }}<t_{\text {tabel }}$ dan nilai ini tidak signifikan pada tingkat signifikasi 0,05 karena lebih besar 0,05 maka hipotesis 1 ditolak, artinya kepemilikan institusional tidak berpengaruh terhadap pengungkapan CSR. Semakin tinggi kepemilikan institusioanl dalam perusahaan maka pengungkapan CSR menurun ataupun sebalik nya. Hasil penelitian ini sejalan dengan penelitian (Widya Novita Dan Puspita 
Rani, 2015) yang menyatakan pada saat kepemilikan institusioanl tinggi dalam perusahaan maka saham yang dimiliki oleh masyarakat publik Pengaruh negatif. Dapat ditimbulkan karena fokus dari pemilik institusional yang berupa lembaga, instansi atau perusahaan tersebut adalah berupa laba dari perusahaan yang akan berdampak langsung pada return yang akan didapatkan oleh pemilik institusional dari investasi di perusahaan. Dengan demikian, semakin besar kepemilikan institusional, tuntutan perusahaan untuk menghasilkan laba akan semakin besar sehingga perusahaan terdorong untuk melakukan efisiensi biaya termasuk biaya yang dikeluarkan perusahaan untuk aktivitas tanggung jawab sosialnya.

\section{Pengaruh Ukuran Dewan Komisaris $\left(\mathrm{X}_{2}\right)$ Terhadap Pengungkapan CSR (Y)}

Dari hasil uji t, diperoleh nilai $t_{\text {hitung }} 3,556$ dan. tabel sebesar 1.979 dengan nilai signifikasi ,001. Dimana didapatkan $t_{\text {hitung }}>t_{\text {tabel }}$ dan nilai ini signifikan pada tingkat signifikasi 0,05 karena lebih kecil dari 0,05 maka hipotesis 2 diterima. Artinya Ukuran Dewan Komisaris berpengaruh terhadap pengungkapan CSR. Karena semakin besar jumlah anggota dewan komisaris maka akan semakin mudah untuk mengandalikan CEO Penelitian ini sejalan dengan Penelitan (Iswandika et al, 2014) karena hal ini mengimplikasikan bahwa semakin mudah untuk mengendalikan CEO dan monitoring yang dilakukan akan semakin efektif

\section{Pengaruh Ukuran Perusahaan Terhadap Pengungkapan CSR (Y)}

Dari hasil uji t, diperoleh thitung 0,288 dan $t_{\text {tabel }}$ sebesar 1,979 dengan nilai signifikasi 0,774 Dimana didapatkan $t_{\text {hitung }}<t_{\text {tabel }}$ dan nilai ini tidak signifikan pada tingkat signifikasi 0,05 karena lebih besar 0,05 maka hipotesis 3 ditolak artinya Ukuran Perusahaan tidak berpengaruh signifikan terhadap pengungkapan CSR. Penelitian ini sejalan dengan (Kastamutuwardhani dan Khairunnisa, 2019) yang mengatakan bahwa tidak adanya pengaruh ukuran perusahaan terhadap pengungkapan CSR. dapat disimpulkan bahwa seberapa besar ukuran perusahaan tidak akan mempengaruhi perusahaan dalam melakukan tanggung jawab sosialnya. Karena tanggung jawab sosial perusahaan merupakan hal yang perlu dilakukan oleh perusahaan tanpa melihat ukuran dari perusahaan tersebut

\section{Ukuran Komite Audit $\left(\mathbf{X}_{4}\right)$ Terhadap Pengungkapan CSR (Y)}

Dari hasil uji t, diperoleh $t_{\text {hitung }} 2,199$ dan $t_{\text {tabel }}$ sebesar 1,979 dengan nilai signifikasi 0,030 Dimana didapatkan $t_{\text {hitung }}>t_{\text {tabel }}$ dan nilai ini signifikan pada tingkat signifikasi 0,05 karena lebih kecil dari 0,05 maka hipotesis 4 diterima artinya Komite Audit berpengaruh terhadap pengungkapan CSR. Berdasarkan teori hasil penelitian dapat di interpretasikan bahwa semakin besar jumlah komite audit pada perusahaan high profile maka semakin besar perusahaan dalam mengungkapkan CSR. Pada perusahaan high profile Semakin banyak jumlah komite audit, maka semakin baik fungsi pengawasan yang diberikan sehingga kegiatan sosial berjalan dengan lancar dan legitimasi dapat terjaga. Penelitian ini sejalan dengan (Aditya et al, 2016) yang menyatakan Semakin banyak jumlah komite audit, maka semakin baik fungsi pengawasan yang diberikan sehingga kegiatan sosial berjalan dengan lancar dan legitimasi dapat terjaga.

\section{PENUTUP \\ Simpulan}

Berdasarkan hasil dari peneliti ini adalah untuk memberikan bukti mengenai pengaruh kepemilikan institusional, ukuran dewan komisaris, ukuran perusahaan, dan ukuran komite audit terhadap tanggung jawab sosial atau Corporate Social Responsibility (CSR). Sampel yang digunakan adalah perusahaan industri dasar dan kimia yang terdaftar di Bursa Efek Indonesia (BEI) tahun 2014-2017 sebanyak 32 perusahaan. Analisis dalam penelitian ini dapat disimpulkan sebagai berikut:

1. Kepemilikan Institusional secara Parsial tidak berpengaruh dan Signifikan terhadap CSR.

2. Kepemilikan Ukuran Dewan Komisaris secara Parsial berpengaruh dan Signifikan terhadap CSR.

3. Kepemilikan Ukuran Perusahaan secara Parsial tidak berpengaruh dan Signifikan terhadap CSR.

4. Kepemilikan Ukuran Komite Audit secara Parisal berpengaruh dan Signifikan terhadap CSR. 


\section{Saran}

Adapun saran yang dapat diberikan melalui hasil penelitian ini agar mendapatkan hasil yang lebih baik, yaitu:

1. Untuk peneliti kedepan nya disarakan kan untuk menambah luas atau jumlah data dan periode penelitian yang lebih panjang/banyak dan terbaru.

2. Peneliti selanjutnya dapat menambahkan dan menguji variabel lain yang diduga dapat memengaruhi pengungkapan CSR seperti kepemilikan saham publik, Umur Perusahaan, ukuran dewan direksi,kepemilikan managerial, profil perusahaan, likuiditas dan sebagainya.

3. Penelitian ini hanya mengkhususkan pada perusahaan Industri dasar dan kimia sebagai populasi penelitian. Pada penelitian selanjutnya diharapkan agar memperluas sektor perusahaan sehingga mampu memberikan kontribusi penelitian bagi seluruh perusahaan.

\section{DAFTAR PUSTAKA}

Aditya D.K. And Novrys S. (2016). FaktorFaktor yang Mempengaruhi Pengungkapan Tanggung Jawab Sosial. Jurnal Akuntansi dan Keuangan, 119128.

Kastamutuwardhani, D. and Khairunnisan. (2019). Pengaruh Profitabilitas, Leverage Dan Ukuran Perusahaan Terhadap Pengungkapan CSR (Studi Kasus pada Perusahaan yang Terdaftar pada Indeks SRI-Kehati Tahun 2013-2017). Jurnal Akuntansi, Audit dan Sistem Informasi Akuntansi, Vol 3(No 02).

Iswandika. R, Murtanto, Sipayung. E. (2014). Pengaruh Kinerja Keuangan, Corporate Governance, dan Kualitas Audit terhadap Pengungkapan Corporate Social Responsibility. e-Journal Akuntansi Fakultas Ekonomi, Vol.1(No.2), 1-18.

Widya Novita Sari., Puspita Rani. (2015). Pengaruh kepemilikan institusional, kepemilikan manajerial, Return On Assets (ROA) dan ukuran perusahaan terhadap pengungkapan Corporate Social Responsibility (CSR) pada perusahaan manufaktur yang terdaftar di Bursa Efek Indonesia periode 2011-2013. Jurnal Akutansi dan Keuangan, Vol 4.66 
